\title{
PERAN PENDIDIKAN KEWIRAUSAHAAN TERHADAP INOVASI MAHASISWA YANG DIMEDIASI PENGENALAN PELUANG WIRAUSAHA
}

\author{
Dita Maharani Suwardi ${ }^{1}$, Amir Machmud ${ }^{2}$, Iswanti ${ }^{3}$ \\ Universitas Pendidikan Indonesia ${ }^{1}$, Universitas Pendidikan Indonesia ${ }^{2}$, Universitas Pendidikan \\ Indonesia $^{3}$ \\ dita.ms@upi.edu ${ }^{1}, \underline{\text { amirmachmud@upi.edu }}{ }^{2}, \underline{\text { iswanti@upi.edu }}{ }^{3}$
}

\begin{abstract}
This research aims to find out and analyze the role of mediation from the introduction of entrepreneurial opportunities to entrepreneurial education and innovation. This research is quantitative research with survey method. The research population is students majoring in economic education siliwangi University with the number of respondents taken amounted to 183 respondents using the formula Slovin and purposive sampling techniques. The data has been collected and processed using track analysis techniques. The results of the analysis prove that the variables of entrepreneurial education and entrepreneurial opportunities recognition have a significant influence on innovation, as well as the role of entrepreneurial opportunities recognition capable of mediating entrepreneurial education to innovation. This means that entrepreneurial education variables influence innovation mediated by entrepreneurial opportunities recognition. The results of this study provide implications that with entrepreneurial opportunities recognition can help students know their entrepreneurial orientation by being encouraged by the entrepreneurial education obtained in the study so that students can foster innovation in students.
\end{abstract}

Keywords: Entrepreneurship Education, Innovation, Entrepreneurial Opportunities Recognition.

\section{Pendahuluan}

Kehadiran revolusi industri 4.0 memang menghadirkan lini usaha baru, lapangan kerja baru, profesi baru yang tak terpikirkan sebelumnya (Ghufron, 2018). Industri 4.0 merupakan zaman perubahan teknologi lama menjadi teknologi digital karena adanya inovasi yang terus berkembang, salah satunya otomatisasi dan konektivitasnya disalah satu sisi akan membuat pergerakan dalam dunia industri dan persaingan dalam dunia kerja menjadi tidak selaras. Salah satu ciri khasnya adalah penerapan kecerdasan buatan (artificial intelligence) (Tjandrawinata, 2016). Berdasarkan analisis McKinsey Global Institute, Revolusi Industri 4.0 telah berkontribusi besar pada sektor lapangan kerja yang menurut mereka diperdiksikan sebanyak 375 juta pekerja diseluruh dunia yang mengharuskan untuk beralih profesi dan mempelajari keterampilan baru, jika proses pengaplikasiaan otomasi tersebut bejalan dengan cepat. Akan tetapi, jika proses perubahan mereka ke profesi baru lambat, maka akan berdampak pada jumlah pengangguran yang dapat meningkat ( Asih, Kamil, \& Indrapriyatna, 2020).

Salah satu cara dalam mengatasi angka pengangguran yang terus meningkat yaitu dengan menciptakan seorang wirausaha. Perguruan tinggi memiliki peran penting dalam merangsang mahasiswa untuk menjadi entrepreneur sehingga menciptakan lapangan pekerjaan baru, salah satu caranya ialah merubahan mindset mahasiswa dari pencari kerja menjadi menciptakan lapangan kerja. Jika mindset sudah tertanam dalam diri mahasiswa, maka dapat merealisasikan ide bisnisnya (Asih, Kamil, \& Indrapriyatna, 2020).

Kewirausahaan telah dipercaya sebagai kekuatan penting dalam pertumbuhan ekonomi global yang menciptakan usaha baru dan pertumbuhan ekonomi (Minniti et al., 2005). Pentingnya kewirausahaan mendorong pengajaran pendidikan kewirausahaan pada tingkat pendidikan paling mendasar sampai Perguruan Tinggi. Posisi pendidikan kewirausahaan sebagai pusat kegiatan instruksional mempengaruhi mahasiswa dalam meningkatkan kapabilitasnya melalui pembelajaran kolaboratif, inovati dan kreatif. Bentuk pengajaran didesain agar bisa memfasilitasi karakter wirausaha mahasiswa, termasuk menyediakan

DOI: 10.33603/ejpe.v9i1.4595

This is an open access article under the CC-BY-SA license 
fasilitas untuk praktek dan menjalankan usaha nyata atau bahkan mulai merintis usahanya (Harwiki, 2019).

Sebab itu, pendidikan kewirausahaan begitu penting bagi masyarakat terutama mahasiswa. Maka Dirjen Pendidikan Perguruan Tinggi (DIKTI) memberlakukan program mata kuliah kewirausahaan yang wajib diikuti mahasiswa. Program pendidikan kewirausahaan selain sebagai kewajiban dalam proses pelaksanaan perkuliahan, diharapkan dapat memenuhi aspek pendekatan sosial dan ekonomi. Dimana melalui pendekatan sosial mahasiswa setelah lulus dapat membuat lapangan kerja baru bagi lingkungan sekitarnya. Sedangkan pendekatan ekonomi, mahasiswa yang menjadi seorang entrepreneur mampu menghasilkan pendapatan untuk dirinya sendiri, orang lain, maupun pemerintah (Murdjianto \& Wahid, 2006).

Pendidikan kewirausahaan diartikan cara bentuk lembaga pendidikan menanamkan pengetahuan, nilai, jiwa dan sikap kewirausahaan kepada peserta didik, agar peserta didik siap menghadapi tantangan serta menjadi manusia yang mandiri, kreatif dan inovatif. Oleh karena itu, dengan tertanamnya hal tersebut pada diri peserta didik akan terciptanya wirausaha baru yang handal dan berkarakter, serta mampu meningkatkan kesejahteraan masyarakat. Selain itu, dapat digunakan sebagai alat untuk menanggulangi pengangguran dan kemiskinan, sehingga menjadikan tonggak dalam menuju harapan masyarakat untuk mandiri secara finansial, memiliki keterampilan membangun kemakmuran individu, serta secara serempak membangun kesejahteraan masyarakat (Ma'mur, 2011).

Selain itu, pendidikan kewirausahaan dapat diartikan sebagai cara penting bagi seorang wirausaha untuk memperoleh sumber daya, meningkatkan kemampuan dan kepribadian inovatif, serta membangun saluran pembelajaran multi-level bagi seorang wirausaha dengan mengintegrasikan berbagai pengetahuan dan sistem nilai. Selain mengenai pembelajaran pengetahuan hingga peningkatan keterampilan, pendidikan kewirausahaan juga mencakup pengembangan kemampuan umum dan peningkatan kemampuan profesional (Kettunen et al., 2013). Pendidikan kewirausahaan menurut Wei, Liu, \& Sha, (2019) menitikberatkan pada perspektif kognitif sosial dari aspek lingkungan, organisasi, serta pembelajaran dan perilaku individu. Terdapat tiga aspek utama yaitu suasana kewirausahaan, kurikulum kewirausahaan, dan kegiatan kewirausahaan.

Binks et al., (2006) berpendapat bahwa pendidikan kewirausahaan berkaitan dengan pengembangan keterampilan kreatif yang dapat diterapkan dalam praktik, pendidikan, dan lingkungan yang mendukung inovasi. Pendidikan kewirausahaan menumbuhkan bakat inovatif menjadikan kekuatan pendorong untuk pengembangan di masa depan. Saat ini, strategi pengembangan yang didorong oleh inovasi menempatkan tuntutan baru pada pendidikan kewirausahaan. Namun, sebagian besar penelitian dan diskusi mengenai pendidikan kewirausahaan berfokus pada pembangunan staf pengajar dalam ekosistem pendidikan kewirausahaan, pengembangan kurikulum, dan apakah pendidikan kewirausahaan dapat mempengaruhi niat kewirausahaan. Padahal saat ini hal penting yang menjadi sorotan dalam kewirausahaan adalah inovasi (Wei, Liu, \& Sha, 2019). Inovasi dan kewirausahaan diakui secara umum bahwa kedua hal tersebut diperlukan untuk menciptakan lompatan baru, dengan demikian dapat berkembang serta bersaing secara internasional. Inovasi dan kewirausahaan dianggap menjadikan cara dalam mengatasi masa sulit, seperti krisis keuangan yang terjadi akhir-akhir ini (Oukil, 2009).

Inovasi adalah kekuatan pendorong untuk pengembangan proyek kewirausahaan. Fokus pendidikan kewirausahaan bukan pada transfer pengetahuan teoritis di dalam kelas tetapi pada tindakan untuk meningkatkan keterampilan profesional kewirausahaan (Kassean et al., 
2015). Selain itu, Duening, Hisrich, \& Lechter (2009) menjelaskan inovasi adalah bakat dalam mengaplikasikan kreatifitas untuk menyelesaikan permasalahan, menemukan peluang, serta memiliki ide baru dan berbeda. Arti dari baru dan berbeda tersebut ialah dapat menciptakan suatu produk yang baru dan berbeda baik dalam bentuk barang maupun jasa ataupun pada prosesnya seperti ide, metode dan cara sehingga memiliki ciri khasnya tersendiri. Inovasi dipandang sebagai pendorong internal dan berkaitan dengan pola pikir kewirausahaan. Dengan demikian, pengembangan produk baru atau pintu masuk ke pasar baru adalah hasil kewirausahaan (Covin, Jeffrey \& Slevin, Dennis, 1989).

Franke, \& Lüthje (2004) menjelaskan bahwa pandangan mahasiswa mengenai pendidikan kewirausahaan terkait dengan persepsi inovasi dalam mendorong inovasi melalui pendidikan kewirausahaan adalah tugas utama perguruan tinggi. Menurut Ding, (2017) faktor kunci yang berdampak pada inovasi dan pendidikan kewirausahaan bagi mahasiswa antara lain bahwa kesadaran akan inovasi dan kemampuan wirausaha perlu ditingkatkan, dan kekuatan pendorong perlu diperkuat. Kesadaran inovatif dan kemampuan inovatif adalah proses inti dari kegiatan inovasi, yang juga dipengaruhi oleh kepribadian inovasi.

Inovasi memiliki makna penting yang mencakup: (1) pembaruan: nilai tambah baru bagi penggunanya atas produk, proses atau jasa, (2) perubahan dalam bentuk transformasi, difusi yang berujung pada perubahan, (3) keunggulan: inovasi produk, proses, metode, teknologi dan manajemen (Suryana, 2014). Sedangkan inovasi mahasiswa menurut Wei, Liu, \& Sha (2019) terdapat tiga indikator dalam mengukur inovasi mahasiswa, seperti mengukur kesadaran inovasi, kemampuan inovasi, dan kepribadian inovasi pengusaha mahasiswa. Melalui inovasi, seorang entrepreneur akan merasa terbantu karena hal tersebut menjadikan peluang bagi usahanya jika saja sanggup dan mampu untuk melakukan penilaian secara berkesinambungan melalui proses menciptakan, mengamati, dan menganalisa secara intens serta memperhitungkan acaman yang mungkin terjadi di masa mendatang (Manurung, 2013).

Selain inovasi, dalam kompetensi kewirausahaan yang paling utama ialah kemampuan untuk mengidentifikasi peluang dan mengembangkan sumber daya dan modal yang diperlukan (Kettunen et al., 2013). Peluang wirausaha adalah kondisi di mana barang baru, jasa, bahan baku dan metode pengelolaan diterapkan, sehingga terjadi penjualan dalam jumlah yang lebih besar dibandingkan biaya yang dikeluarkan (Shane \& Venkataraman, 2000). Mengetahui akan peluang didefinisikan sebagai proses mengenali ide baru dan ide yang berpotensi berhasil, yang dipengaruhi oleh karakteristik individu dan faktor kontekstual (Eckhardt \& Shane, 2003). Wei, Liu, \& Sha (2019) berpendapat bawa pengenalan peluang berwirausaha merupakan bagian utama pada tahap awal mahasiswa akan berwirausaha; ini adalah proses memahami dan menilai permintaan pasar dengan benar, dan terus memproses sumber daya terkait yang diperoleh dalam pembelajaran kewirausahaan untuk membentuk kemampuan inovatif dan kepribadian mereka. Harwiki, (2019) membuktikan bahwa karakteristik peluang kewirausahaan meliputi situasi, keyakinan dan perilaku. Menurut Cai et al., (2014) mengukur kemampuan wirausaha mahasiswa dalam mengidentifikasi peluang baru, dilakukan dengan empat indikator seperti "produk dan layanan yang dapat secara efektif mengidentifikasi kebutuhan pelanggan". Sedangkan Manurung, (2013) mengatakan seorang wirausaha yang menginginkan untuk memiliki peluang wirausaha harus mempunyai keterampilan dan pengetahuan, seperti menciptakan produk atau jasa yang baru, menciptakan nilai tambah baru, membangun usaha baru, menciptakan suatu proses atau teknik baru, serta menciptkan dan mengembangkan organisasi baru.

Salah satu perguruan tinggi yang mengadakan pendidikan mengenai kewirausahaan adalah Universitas Siliwangi. Universitas Siliwangi merupakan perguruan tinggi negeri yang

p-ISSN 2337-571X | e-ISSN $\underline{2541-562 X}$ 
berada di Kota Tasikmalaya, Jawa Barat. Universitas Siliwangi sebagai salah satu lembaga pendidikan memiliki misi dan tujuan, salah satunya ialah menyelenggarakan pendidikan untuk menghasilkan lulusan yang berwawasan kebangsaan dan berjiwa wirausaha dan menghasilkan lulusan yang memiliki pengetahuan, keterampilan, dan wawasan kebangsaan serta kewirausahaan dalam bidang keilmuan masing-masing. Misi dan tujuan tersebut diharapkan mampu menumbuhkan intensi berwirausaha, serta siap membangun karir sebagai seorang wirausahawan dengan bekal pendidikan kewirausahaan yang sudah mereka pelajari selama menuntut ilmu. Hal ini khususnya pada mahasiswa pendidikan ekonomi yang telah mempelajari kewirausahaan pada mata kuliah pendidikan kewirausahaan.

Penelitian yang dilakukan Wei, Liu, \& Sha, (2019) mengenai pengaruh pendidikan kewirausahaan terhadap inovasi membuat peneliti tertarik untuk melakukan penelitian tersebut di Universitas Siliwangi, serta belum ada yang melakukan penelitian hal ini sebelumnya. Berdasarkan latar belakang tersebut fokus dari penelitian ini adalah untuk menganalisis peran pendidikan kewirausahaan terhadap inovasi mahasiswa yang dimediasi oleh pengenalan peluang wirausaha. Penelitian sebelumnya telah banyak membahas inovasi pada mahasiswa secara umum, tetapi pembahasan mengenai pengenalan akan peluang wirausaha pada diri mahasiswa setelah mengikuti pendidkan kewirausahaab masih terbatas dan jarang dilakukan penelitian akan hal tersebut. Oleh sebab itu, penelitian ini dilakukan untuk melengkapi gap pada penelitian terdahulu.

Penelitian ini bertujuan untuk mengetahui dan menganalisis (1) pengaruh pendidikan kewirausahaan terhadap inovari mahasiswa Pendidikan Ekonomi Universitas Siliwangi, (2) pengaruh pendidikan kewirausahaan terhadap pengenalan peluang wirausaha pada mahasiswa Pendidikan Ekonomi Universitas Siliwangi, (3) inovasi terhadap pengaruh pengenalan peluang wirausaha pada mahasiswa Pendidikan Ekonomi Universitas Siliwangi, (4) pengaruh pendidikan kewirausahan terhadap inovasi mahasiswa melalui pengenalan peluang wirausaha mahasiswa Pendidikan Ekonomi Universitas Siliwangi. Kerangka hipotesis pada penelitian ini adalah sebagai.

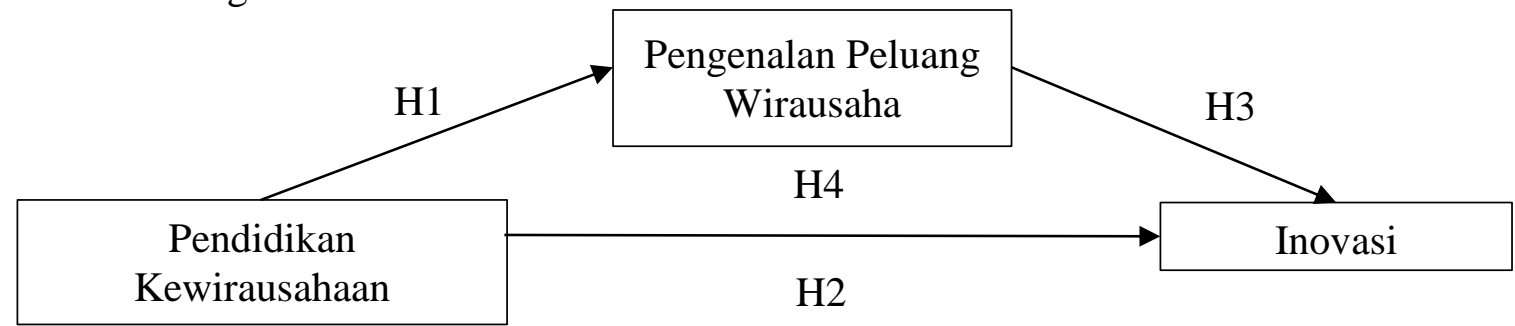

\section{Gambar 1. Kerangka Hipotesis}

Dari konsep penelitian tersebut maka dihasilkan hipotesis positif sebagai berikut:

1. Pendidikan kewirausahaan mempengaruhi pengenalan peluang wirausaha.

2. Pendidikan kewirausahaan mempengaruhi inovasi mahasiswa.

3. Pengenalan peluang wirausaha mempengaruhi inovasi mahasiswa.

4. Pengenalan peluang wirausaha memiliki peran mediasi dalam hubungan pendidikan kewirausahaan dan inovasi mahasiswa.

\section{Metode Penelitian}

Lokasi penelitian dilakukan di Universitas Siliwangi, Tasikmalaya. Jenis penelitian ini adalah penelitian korelasional dengan pendekatan kuantitatif. Lokasi penelitian dilakukan pada salah satu perguruan tinggi di Tasikmalaya, yaitu Unvesitas Siliwangi. Populasi dalam penelitian ini adalah mahasiswa pendidikan ekonomi Universitas Siliwangi, dan teknik 
sampel yang digunakan adalah purposive sampling dengan kriteria yang digunakan adalah mahasiswa pendidikan ekonomi angkatan 2016-2018 dan masih status aktif kuliah, serta telah mengikuti mata kuliah pendidikan kewirausahaan.

\section{Tabel 1}

Jumlah Data Mahasiswa Pendidikan Ekonomi Universitas Siliwangi 2016-2018

\begin{tabular}{|c|c|}
\hline $\begin{array}{c}\text { Tahun } \\
\text { Angkatan }\end{array}$ & $\begin{array}{c}\text { Jumlah } \\
\text { Mahasiswa }\end{array}$ \\
\hline 2016 & 111 \\
\hline 2017 & 117 \\
\hline 2018 & 108 \\
\hline Jumlah & 336 \\
\hline
\end{tabular}

Sumber : Bagian Akademik FKIP Ekonomi, 2020

Perhitungan sampel mahasiswa dilakukan dengan rumus Slovin yaitu sebagai berikut: $\mathrm{n}=\frac{\mathrm{N}}{1+\mathrm{Ne}^{2}}$

Keterangan:

$\mathrm{n} \quad=$ Jumlah sampel penelitian

$\mathrm{N} \quad=$ Jumlah populasi penelitian

e $\quad=$ persen kelonggaran ketidaktelitian kesalahan (menggunakan taraf kesalahan 5\%)

Diketahui

$$
\begin{aligned}
& \mathrm{N} \quad=336 \\
& \mathrm{e} \quad=0.05 \\
& =\frac{336}{1+336(0,05)^{2}} \\
& =\frac{336}{1+0,84} \\
& =\frac{336}{1,84} \\
& =182,6 \ldots .
\end{aligned}
$$

Sampel diperoleh sebanyak 183 mahasiswa, selanjutnya sampel dibagi menurut tingkat tahun angkatan. Sehingga jumlah sampel mahasiswa setiap angkatan terdapat pada Tabel 2.

Tabel 1

Perhitungan dan Distribusi Sampel Mahasiswa Pendidikan Ekonomi Universitas Siliwangi 2016-2018

\begin{tabular}{ccccc}
\hline No & $\begin{array}{c}\text { Tahun } \\
\text { Angkatan }\end{array}$ & $\begin{array}{c}\text { Jumlah } \\
\text { Mahasiswa }\end{array}$ & $\begin{array}{c}\text { Perhitungan } \\
\text { Sampel }\end{array}$ & $\begin{array}{c}\text { Jumlah } \\
\text { Sampel }\end{array}$ \\
\hline 1. & 2016 & 111 & $\mathrm{ni}=\frac{111}{336} \times 183$ & 59 \\
\hline 2. & 2017 & 117 & $\mathrm{ni}=\frac{117}{336} \times 183$ & 64 \\
\hline 3. & 2018 & 108 & $\mathrm{ni}=\frac{108}{336} \times 183$ & 60 \\
\hline & Jumlah & 336 & & 183 \\
\hline
\end{tabular}

Sumber: Data Primer, diolah (2020)

Penelitian ini menggunakan variabel dependen inovasi mahasiswa, variabel independen pendidikan kewirausahaan, dan variabel mediasi pengenalan peluang wirausaha. 
Penelitian ini menggunakan teori pengetahuan sosial untuk menguji bagaimana mahasiswa dalam pendidikan kewirausahaan dapat meningkatkan kemampuan mereka untuk mengidentifikasi pengenalan peluang wirausaha yang mempengaruhi kesadaran inovatif, kemampuan inovatif, dan kepribadian inovatif wirausaha.

Teknik pengumpulan data mengunakan teknik observasi, angket dan dokumentasi. Angket atau pengumpulan data dengan kuesioner digunakan untuk mengukur variabel pendidikan kewirausahaan mahasiswa, inovasi mahasiswa dan pengenalan peluang wirausaha pada mahasiswa. Pada pelaksanaan penelitian mahasiswa diarahkan untuk mengisi angket tersebut berdasarkan keadaan diri mereka sebenarnya. Skala pengukuran yang digunakan ialah skala Likert. Instrumen penelitian pada kuesioner yang telah disusun, diuji cobakan terlebih dahulu untuk dilakukan uji validitas dan reliabilitas. Teknik analisis dalam penelitian menggunakan statistik deskriptif dan statistik inferensial.

\section{Hasil dan Pembahasan \\ Karakeristik Responden}

Sampel penelitian digambarkan secara umum yang menyajikan karakteristik responden dengan dikelompokan dari jenis kelamin dan tahun angkatan. Jumlah sampel penelitian yang digunakan sebanyak 183 orang, berdasarkan hasil yang diperoleh dari perhitungan sampel dengan menggunakan rumus Slovin. Penjelasan rinci dan jelasnya, mengenai gambaran karakteristik responden berdasarkan demografi terdapat pada Tabel 3.

\section{Tabel 3}

Karakteristik Responden

\begin{tabular}{lccc}
\hline & Kriteria & Frekuensi & $\begin{array}{c}\text { Persentase } \\
\text { \% }\end{array}$ \\
\hline Jenis Kelamin & Laki-laki & 42 & 22,95 \\
& Perempuan & 141 & 77,05 \\
Tahun Angkatan & 2016 & 59 & 32,24 \\
& 2017 & 64 & 34,97 \\
& 2018 & 60 & 32,79 \\
\hline \hline
\end{tabular}

Berdasarkan Tabel 3 didapatkan pengelompokan responden berdasarkan jenis kelamin, menunjukkan bahwa jumlah responden laki-laki dengan persentase sebesar 22,95\% dan perempuan sebesar 77,05\%. Pengelempokan berikutnya berdasarkan tahun angkatan, menunjukan bahwa tahun angkatan 2016 dengan persentasi sebesar 32,24\%, 2017 sebesar $34,97 \%$, dan 2018 sebesar 32,79\%.

\section{Statistik Desktiptif dan Uji Korelasi}

Analisis statistik deskriptif dan uji korelasi secara statistik dibantu menggunakan SPSS. Statistik deskriptif menganalisis mengenai nilai minimum, maksimum, rata-rata, varian, dan standar deviasi yang disajikan pada Tabel 4. Berdasarkan pada Tabel 5 uji korelasi, koefisien korelasi antar variabel menunjukan bahwa terdapat korelasi yang signifikan antara pendidikan kewirausahaan, pengenalan peluang wirausaha, dan inovasi. Hasil dari statistik deskriptif dan uji korelasi yang menggambarkan hubungan antar variabel, serta memberikan dasar untuk analisis data lebih lanjut. 
Tabel 4

Statistik Deskriptif Variabel Penelitian

\begin{tabular}{cccccccc}
\hline \hline Variabel & Range & Min. & Maks. & \multicolumn{2}{c}{ Mean } & Varians & Std. Dev \\
\cline { 2 - 7 } Penelitian & Statistic & Statistic & Statistic & Statistic & $\begin{array}{c}\text { Std. } \\
\text { Error }\end{array}$ & Statistic & Statistic \\
\hline $\begin{array}{c}\text { Pendidikan } \\
\text { Kewirausahaan }\end{array}$ & 40 & 42 & 82 & 67,13 & 0,481 & 42,334 & 6,506 \\
$\begin{array}{c}\text { Inovasi } \\
\text { Pengenalan } \\
\text { peluang }\end{array}$ & 30 & 49 & 79 & 64,81 & 0,429 & 33,716 & 5,807 \\
wirausaha & 35 & 51 & 86 & 68,55 & 0,444 & 36,106 & 6,009 \\
\hline \hline
\end{tabular}

Tabel 5

Uji Korelasi

\begin{tabular}{|c|c|c|c|c|}
\hline & & $\begin{array}{c}\text { Pendidikan } \\
\text { Kewirausahaan }\end{array}$ & Inovasi & $\begin{array}{c}\text { Pengenalan } \\
\text { peluang } \\
\text { wirausaha }\end{array}$ \\
\hline \multirow{3}{*}{$\begin{array}{c}\text { Pendidikan } \\
\text { Kewirausahaan }\end{array}$} & Pearson Correlation & 1 & & \\
\hline & Sig. (2-tailed) & & & \\
\hline & $\mathrm{N}$ & 183 & & \\
\hline \multirow{3}{*}{ Inovasi } & Pearson Correlation &, $387^{* * *}$ & 1 & \\
\hline & Sig. (2-tailed) & ,000 & & \\
\hline & $\mathrm{N}$ & 183 & 183 & \\
\hline \multirow{3}{*}{$\begin{array}{c}\text { Pengenalan } \\
\text { peluang } \\
\text { wirausaha }\end{array}$} & Pearson Correlation & $647^{\text {** }}$ & $373^{* *}$ & 1 \\
\hline & Sig. (2-tailed) & ,000 & ,000 & \\
\hline & $\mathrm{N}$ & 183 & 183 & 183 \\
\hline
\end{tabular}

\section{Analisis Jalur dan Kelayakan Model}

Uji hipotesis ini mengikuti Wibowo \& Pramudana, (2016) yang menggunakan teknik analisis jalur. Analisis jalur merupakan pengembangan dari uji regresi khususnya uji regresi linear berganda, yang digunakan untuk menganalisis hubungan kausalitas dua atau lebih variabel. Berikut adalah penyelesaian dan pengujian hipotesis menggunakan analisis jalur dan kelayakan model.

Tabel 6

Hasil Analisis Persamaan Regresi 1

\begin{tabular}{ccccccc}
\hline \multirow{2}{*}{$\begin{array}{c}\text { Variabel } \\
\text { Penelitian }\end{array}$} & \multicolumn{2}{c}{$\begin{array}{c}\text { Unstandardized } \\
\text { Coefficients }\end{array}$} & $\begin{array}{c}\text { Standardized } \\
\text { Coefficients }\end{array}$ & t & Sig. \\
\cline { 2 - 4 } & $\mathbf{B}$ & $\begin{array}{c}\text { Std. } \\
\text { Error }\end{array}$ & Beta & & \\
\hline (Constant) & 28,460 & 3,532 & & & 8,058 & 0,000 \\
\hline $\begin{array}{c}\text { Pendidikan } \\
\text { Kewirausahan }\end{array}$ & 0,597 & 0,052 & 0,647 & & 11,404 & 0,000 \\
\hline
\end{tabular}




\begin{tabular}{ll}
\hline $\mathrm{F} \quad=130,041$ \\
Sig. $\mathrm{F}=0,000$ \\
$\mathrm{R}^{2} \quad=0,418$ \\
*Dependent variabel: Penganalan Peluang Wirausaha \\
\hline
\end{tabular}

Berdasarkan analisis persamaan regresi 1 seperti yang terdapat pada tabel 6 , diperoleh persamaan sub-struktural, yaitu

Persamaan sub-struktur 1:

$\mathrm{PPW}=\beta_{1} \mathrm{PK}+\mathrm{e}_{1}$

$\mathrm{PPW}=0,597 \mathrm{PK}+\mathrm{e}_{1}$

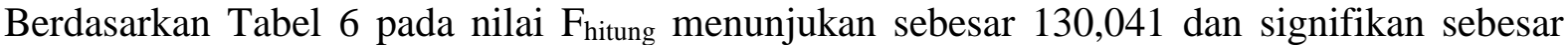
0,000. Nilai signifikan menunjukan lebih kecil dari alpha $(0,05)$, maka maka $\mathrm{H}_{0}$ ditolak dan $\mathrm{H}_{1}$ diterima. Artinya variabel pendidikan kewirausahaan dapat mengestimasi variabel pengenalan peluang wirausaha, atau dapat diartikan bahwa pendidikan kewirausahaan berpengaruh signifikan dan positif terhadap pengenalan peluang wirausaha.

Tabel 7

Hasil Analisis Persamaan Regresi 2

\begin{tabular}{|c|c|c|c|c|c|}
\hline \multirow{2}{*}{$\begin{array}{l}\text { Variabel } \\
\text { Penelitian }\end{array}$} & \multicolumn{2}{|c|}{$\begin{array}{c}\text { Unstandardized } \\
\text { Coefficients }\end{array}$} & \multirow{2}{*}{$\begin{array}{c}\begin{array}{c}\text { Standardized } \\
\text { Coefficients }\end{array} \\
\text { Beta } \\
\end{array}$} & \multirow{2}{*}{$\mathbf{t}$} & \multirow{2}{*}{ Sig. } \\
\hline & B & $\begin{array}{l}\text { Std. } \\
\text { Error }\end{array}$ & & & \\
\hline (Constant) & 35,839 & 4,748 & & 7,547 & 0,000 \\
\hline $\begin{array}{c}\text { Pendidikan } \\
\text { Kewirausahaan }\end{array}$ & 0,224 & 0,079 & 0,250 & 2,823 & 0,005 \\
\hline $\begin{array}{c}\text { Pengenalan } \\
\text { peluang } \\
\text { wirausaha } \\
\end{array}$ & 0,204 & 0,086 & 0,211 & 2,376 & 0,019 \\
\hline $\begin{array}{ll}\mathrm{F} & =19,153 \\
\text { Sig. } \mathrm{F} & =0,000 \\
\mathrm{R}^{2} & =0,175 \\
& \text { *Dependent variab }\end{array}$ & Inovasi & & & & \\
\hline
\end{tabular}

Berdasarkan analisis persamaan regresi 2 seperti yang terdapat pada Tabel 7, diperoleh persamaan sub-struktural, yaitu

Persamaan sub-struktur 2:

$\mathrm{I}=\beta_{3} \mathrm{PK}+\beta_{2} \mathrm{PPW}+\mathrm{e}_{2}$

$\mathrm{I}=0,224 \mathrm{PK}+0,204 \mathrm{PPW}+\mathrm{e}_{2}$

Tabel 7 menunjukan nilai $F_{h i t u n g}$ sebesar 19,153 dengan signifikansi 0,000. Nilai signifikan menunjukan lebih kecil dari alpha $(0,05)$ maka pengujian pada $\mathrm{H}_{2}$ dan $\mathrm{H}_{3}$ diterima. Artinya variabel pendidikan kewirausahaan dan pengenalan peluang wirausaha dapat mengestimasi pada variabel inovasi mahasiswa, atau dapat diartikan bahwa pendidikan kewirausahaan dan pengenalan peluang wirausaha secara serempak berpengaruh signifikan dan positif terhadap inovasi mahasiswa.

Berdasarkan hasil analisis pengujian dari analisis regresi 1 dan 2, maka dapat dibentuk model diagram jalur akhir. Hal pertama dalam menganalisis model diagram jalur akhir, yaitu 
menghitung nilai dari standar eror terlebih dahulu, dengan persamaannya sebagai berikut:

$\mathrm{e}=\sqrt{1-\mathrm{R}_{\mathrm{i}}^{2}}$

$\mathrm{e}_{1}=\sqrt{1-0,418}=0,763$

$\mathrm{e}_{2}=\sqrt{1-0,175}=0,908$

Diperoleh bahwa pengaruh error $1\left(\mathrm{e}_{1}\right)$ sebesar 0,763 dan pengaruh error $2\left(\mathrm{e}_{2}\right)$ sebesar 0,908. Maka dari hasil standar error 1 dan 2, diperoleh nilai koefisien determinasi total dengan persamaan strukturnya, yaitu:

$\mathrm{R}_{\mathrm{m}}^{2}=1-\left(\mathrm{e}_{1}\right)^{2}\left(\mathrm{e}_{2}\right)^{2}$

$\mathrm{R}_{\mathrm{m}}^{2}=1-(0,763)^{2}(0,908)^{2}$

$\mathrm{R}_{\mathrm{m}}^{2}=1-(0,582)(0,824)$

$\mathrm{R}^{2} \mathrm{~m}=1-0,480$

$\mathrm{R}_{\mathrm{m}}^{2}=0,520$

Nilai determinasi total sebesar 0,520 mempunyai arti bahwa sebesar 52\% inovasi mahasiswa dipengaruhi oleh pendidikan kewirausahaan dan pengenalan peluang wirausaha, sedangkan sisanya sebesar $48 \%$ dipengaruhi oleh faktor lain yang tidak dimasukkan ke dalam model. Berdasarkan hasil analisis sub-struktur 1 dan 2 yang diperoleh sebelumnya, maka dapat diketahui berapa besarnya pengaruh langsung, pengaruh tidak langsung dan pengaruh total antar variabel. Ketiga hal tersebut dirumuskan sebagai berikut:

$\mathrm{PK} \rightarrow \mathrm{PPW} \rightarrow \mathrm{I}=\beta_{1} \times \beta_{2}$------------------------------------ (6)

$\mathrm{PK} \rightarrow \mathrm{PPW} \rightarrow \mathrm{I}=0,597 \times 0,204$

$\mathrm{PK} \rightarrow \mathrm{PPW} \rightarrow \mathrm{I}=0,122$

Pengaruh total variabel pendidikan kewirausahaan terhadap inovasi melalui variabel pengenalan peluang wirausaha dirumuskan sebagai berikut:

Pengaruh total $=\beta_{3}+\left(\beta_{1} \times \beta_{2}\right)$

Pengaruh total $=0,224+(0,597 \times 0,204)$

Pengaruh total $=0,346$

\section{Tabel 8}

Pengaruh Langsung, Pengaruh Tidak Langsung serta Pengaruh Total Pendidikan Kewirausahaan, Inovasi, dan Pengenalan Peluang Wirausaha

\begin{tabular}{lccc}
\hline \hline & $\begin{array}{c}\text { Pengaruh } \\
\text { Langsung }\end{array}$ & $\begin{array}{c}\text { Pengaruh Tidak } \\
\text { Langsung } \\
\text { Melalui PPW }\end{array}$ & $\begin{array}{c}\text { Pengaruh } \\
\text { Total }\end{array}$ \\
\hline $\mathbf{P K ~} \rightarrow$ PPW & 0,597 & - & 0,597 \\
$\mathbf{P K ~} \rightarrow$ PPW $\rightarrow$ I & 0,224 & 0,122 & 0,346 \\
$\mathbf{P P W ~} \rightarrow$ I & 0,204 & - & 0,204 \\
\hline \hline
\end{tabular}

*PK: Pendidikan Kewirausahaan, I:Inovasi, PPW: Pengenalan Peluang Wirausaha

Berdasarkan analisis jalur dan kelayakan model dapat diketahui bahwa; (1) pengaruh secara langsung pendidikan kewirausahaan terhadap pengenalan peluang wirausaha adalah sebesar $0,597,(2)$ pengaruh secara langsung pengenalan peluang wirausaha terhadap inovasi adalah sebesar 0,204, (3) pengaruh secara langsung pendidikan kewirausahaan terhadap inovasi adalah sebesar 0,224, dan (4) pengaruh secara tidak langsung pendidikan kewirausahaan terhadap inovasi melalui pengenalan peluang wirausaha adalah sebesar 0,122 . 


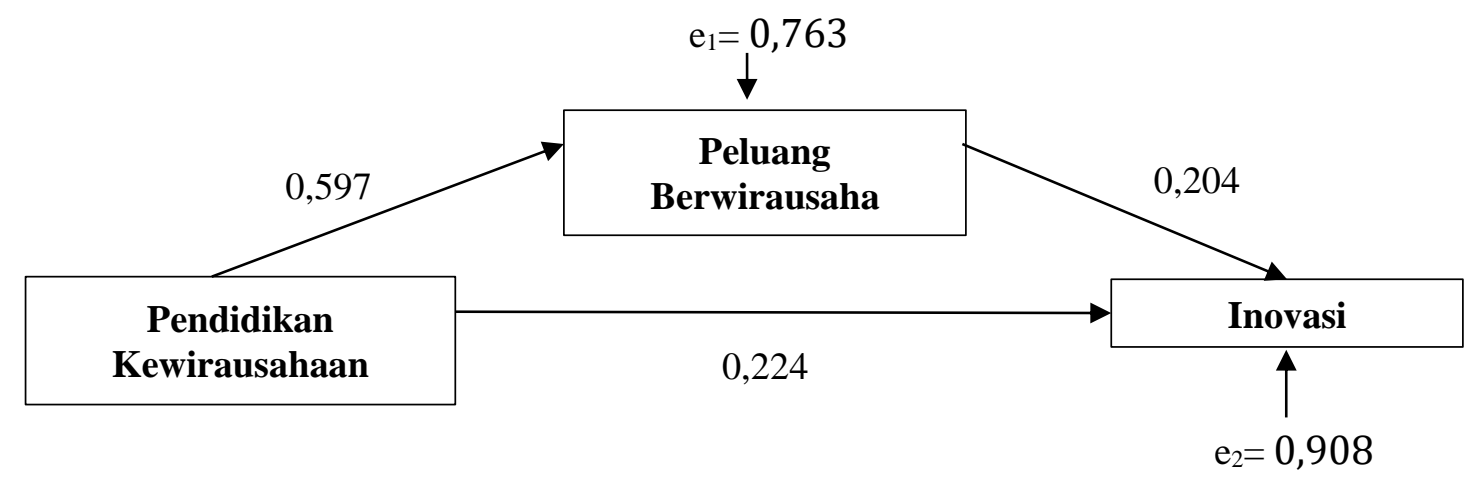

Gambar 2 Validasi Model Diagram Jalur Akhir

\section{Analisis Sobel}

Pengujian variabel moderasi menggunakan uji Sobel, untuk menguji signifikansi pengaruh tidak langsung. Hasil analisis sobel terdapat pada Tabel 9.

Tabel 9

Uji Sobel

\begin{tabular}{cccc}
\hline Sobel Test & Test statistic & Std. Error & p-value \\
\hline $\mathrm{z}$ & 2,323 & 0,052 & 0,020 \\
\hline
\end{tabular}

Hasil uji sobel pada Tabel 9 diperoleh bahwa nilai Zhitung sebesar 2,323 lebih besar dibandingkan dengan nialai $Z_{\text {tabel }}$ sebesar 1,96 maka pengujian pada $\mathrm{H}_{4}$ dapat diterima. Artinya pengenalan peluang wirausaha berpengaruh signifikan dan positif dalam memediasi pendidikan kewirausahaan terhadap inovasi pada mahasiswa Program Pendidikan Ekonomi Universitas Siliwangi.

\section{Pembahasan}

Hipotesis 1: pendidikan kewirausahaan mempengaruhi pengenalan peluang wirausaha.

Hasil uji analisis jalur diperoleh standardized beta sebesar 0,597, thitung sebesar 11,404, dan nilai signifikan sebesar 0,000 lebih kecil dari alpha $(0,05)$ dan nilai keofisien determintasinya diperoleh sebesar 0,418 . Artinya pendidikan kewirausahaan mempengaruhi secara signifikan dan positif terhadap pengenalan peluang wirausaha mahasiswa pendidikan ekonomi, dan sebesar 41,8\% pengenalan peluang wirausaha dipengaruhi oleh pendidikan kewiraushaan. Hasil analisis ini sejalan dengan penelitian Wei, Liu, \& Sha (2019), dan Harwiki, (2019), yang menyatakan bahwa pendidikan kewirausahaan mempengaruhi pengenalan peluang wirausaha. Pendidikan kewirausahaan membantu mahasiswa mengetahui peluang wirausaha. Berdasarkan teori kognitif sosial, setiap individu tidak hanya mempelajari keterampilan tetapi juga membenamkan diri dalam komunitas kewirausahaan sehingga dapat meningkatkan kemampuan mereka untuk mengenali peluang wirausaha dan menangkap peluang wirausaha nyata melalui masyarakat Wei, Liu, \& Sha (2019). Mahasiswa wirausaha dianggap sebagai pelaksana dalam pembelajaran dan praktik kewirausahaan, sehingga 
keterampilan mereka yang tinggi seperti hubungan sosial interpersonal yang baik, dan jejaring sosial yang besar dapat meningkatkan kemampuan mengidentifikasi peluang.

Hipotesis 2: pendidikan kewirausahaan mempengaruhi inovasi mahasiswa.

Hasil uji analisis jalur diperoleh nilai standardized beta sebesar 0,224, thitung sebesar 2,823, dan nilai signifikan sebesar 0,005 lebih kecil dari alpha (0,05). Artinya secara langsung pendidikan kewirausahaan mempengaruhi secara signifikan dan positif terhadap inovasi mahasiswa pendidikan ekonomi. Hal ini sejalan dengan hasil penelitian Wei, Liu, \& Sha (2019), Harwiki (2019), Asih, Kamil, \& Indrapriyatna (2020), Sektiyaningsih \& Aisyah (2020), yang sama-sama menyatakan bahwa pendidikan kewirausahaan mempengaruhi inovasi. Keterampilan yang diperoleh dalam pendidikan kewirausahaan dikaitkan dengan kesadaran inovatif, kemampuan inovatif, kepribadian inovatif, dan menjawab pertanyaan apakah kewirausahaan dan inovasi dapat dilihat. Dengan demikian, pendidikan kewirausahaan memumbuhkan bakat inovatif mahasiswa sehingga peran dalam dampak pendidikan kewirausahaan yang dirasakan pada inovasi.

Hipotesis 3: pengenalan peluang wirausaha mempengaruhi inovasi mahasiswa.

Hasil uji analisis jalur diperoleh nilai standardized beta sebesar 0,204, t hitung sebesar 2,376, dan nilai signifikan sebesar 0,019 lebih kecil dari alpha $(0,05)$. Artinya pengenalan peluang wirausaha mempengaruhi secara signifikan dan positif terhadap inovasi mahasiswa pendidikan ekonomi. Hal ini sejalan dengan hasil penelitian Wei, Liu, \& Sha (2019), yang menyatakan bahwa pengenalan peluang wirausaha mempengruhi inovasi. Kemampuan pengenalan peluang akan wirausha membentuk mahasiswa yang memiliki banyak ide atau gagasan untuk menciptakan sesuatu yang baru sehingga inovasi tercipta.

Hipotesis 4: Pengenalan peluang wirausaha memiliki peran mediasi dalam hubungan pendidikan kewirausahaan dan inovasi mahasiswa

Hasil uji analisis jalur pengujian hipotesis 4 diperoleh bahwa pengaruh secara langsung pendidikan kewirausahaan inovasi tanpa adanya pengenalan peluang wirausaha adalah sebesar 0,224, sedangkan pengaruh secara tidak langsung langsung pendidikan kewirausahaan terhadap inovasi adalah sebesar 0,204. Serta diperoleh nilai keofisien determinasi total sebesar 0,520, artinya 52\% inovasi dipengaruhi oleh pendidikan kewirausahaan dan pengenalan peluang wirausaha, sedangkan sisanya sebesar $48 \%$ dipengaruhi oleh faktor lain yang tidak dimasukkan ke dalam model Hasil uji analisis lainnya yang menggunakan pengujian sobel yang menunjukan nilai $Z_{\text {hitung }}$ sebesar 2,323 > $Z_{\text {tabel }}$ sebesar 1,96, artinya pengenalan peluang wirausaha berpengaruh secara signifikan dan positif dalam memediasi pendidikan kewirausahaan terhadap inovasi mahasiswa Pendidikan Ekonomi Universitas Siliwangi. Hasil penelitian ini sejalan dengan Wei, Liu, \& Sha (2019) mengatakan terdapat hubungan yang positif antara pendidikan kewirausahaan dan inovasi, peluang wirausaha secara individu sebagai mediasi antara pendidikan kewirausahaan dan inovasi.

Implikasi dari hasil penelitian ialah dengan pendidikan kewirausahaan dapat membantu mahasiswa dalam membekali diri menjadi manusia yang mandiri, kreatif dan inovatif. Pendidikan kewirausahaan, membanyak proyek kewirausahaan didasarkan pada transformasi teknologi inovatif dan kreativitas. Inovasi adalah kekuatan pendorong untuk pengembangan proyek kewirausahaan. Fokus pendidikan kewirausahaan bukan pada transfer pengetahuan teoritis di dalam kelas tetapi pada tindakan untuk meningkatkan keterampilan profesional kewirausahaan (Kassean et al., 2015). Melalui partisipasi dalam pembelajaran, mahasiswa membentuk jaringan pembelajaran dalam lingkungan pendidikan kewirausahaan yang baik, menggunakan pengaruh mereka untuk terus memperoleh dan bertukar sumber 
daya yang berharga melalui persuasi dan kolaborasi, membangun jaringan sumber daya sosial bersama, dan meningkatkan keterampilan profesional. Efektivitas dan tingkat konversi pengetahuan inovatif memperkuat dampak pendidikan kewirausahaan yang dirasakan pada inovasi.

\section{Simpulan}

Berdasarkan hasil analisis dapat disimpulkan bahwa, (1) pendidikan kewirausahaan mempengaruhi secara signifikan dan positif terhadap pengenalan peluang wirausaha, (2) pendidikan kewirausahaan mempengaruhi secara signifikan dan positif terhadap inovasi, (3) pengenalan peluang wirausaha mempengaruhi secara signifikan dan positif terhadap inovasi dan (4) pengenalan peluang wirausaha memiliki peran mediasi dalam hubungan pendidikan kewirausahaan dan inovasi baik secara langsung maupun tidak langsung. Artinya bahwa pengenalan peluang kewirausahaan mendorong mahasiswa untuk mengetahui orientasi kewirausahaanya dengan bantuan dari pendidikan kewirausahaan yang diperoleh diperkuliahan sehingga mahasiswa dapat menuangkan kreatifitas dan inovasi dari diri sendiri.

\section{Referensi}

Asih, W. M., Kamil, I., \& Indrapriyatna, A. S. (2020). Peran Pendidikan Kewirausahaan Terhadap Perilaku Inovatif Mahasiswa Dalam Menghadapi Revolusi Industri 4.0. JMKSP (Jurnal Manajemen, Kepemimpinan, dan Supervisi Pendidikan) P-ISSN: 25487094 E-ISSN 2614-8021. 5(1).

Binks, M., Starkey, K., \& Mahon, C. L. (2006). Entrepreneurship education and the business school. Technology Analysis and Strategic Management, 18(1), 1-18. https://doi.org/10.1080/09537320500520411

Cai, L., Tang, S., Ma, Y., \& Gao, X. (2014). The effect of entrepreneurial learning and entrepreneurial capability on new venture performance. Stud. Sci. 32, 1189-1197. https://10.16192/j.cnki.1003-2053.2014.08.029

Covin, Jeffrey, G., \& Slevin, Dennis, P. (1989). Strategic management of small firms in hostile and benign environments. Strategic Management Journal, 10(1), 75-87.

Ding, Y. Y. (2017). The constraints of innovation and entrepreneurship education for university students. Journal of Interdisciplinary Mathematics, 20(6-7), 1431-1434. https://doi.org/10.1080/09720502.2017.1382152

Duening, T. N., Hisrich, R. A., \& Lechter, M. A. (2009). Technology entrepreneurship: Creating, capturing, and protecting value. Academic Press.

Eckhardt, J. T., \& Shane, S. A. (2003). Opportunities and Entrepreneurship. 29(3), 333-349.

Franke, N., \& Lüthje, C. (2004). Entrepreneurial intentions of business students-A benchmarking study. International Journal of Innovation and Technology Management, 1(03), 269-288.

Ghufron, G. (2018). Revolusi Industri 4.0: Tantangan, Peluang, Dan Solusi Bagi Dunia Pendidikan. Seminar Nasional Dan Diskusi Panel Multidisiplin Hasil Penelitian Dan Pengabdian Kepada Masyarakat 2018, 1(1), 332-337.

Harwiki, W. (2019). Pendidikan Kewirausahaan, Disrupsi Inovasi, dan Peluang Kewirausahaan pada Mahasiswa Universitas DR. Soetomo Surabaya. PERWIRA-Jurnal Pendidikan Kewirausahaan ..., 2, 79-89.

https://perwiraindonesia.com/eJournal/index.php/perwira/article/view/11

Kassean, H., \& Vanevenhoven, J. (2015). Entrepreneurship education : a need for reflection, real-world experience and action. https://doi.org/10.1108/IJEBR-07-2014-0123 
Kettunen, J., Kairisto-mertanen, L., \& Penttila, T. (2013). Innovation pedagogy and desired learning outcomes in higher education. 21(4), 333-342. https://doi.org/10.1108/OTH08-2011-0024

Ma'mur, J. (2011). Sekolah Entrepreneur. Jakarta Selatan: Buku Kita.

Manurung, H. (2018). Peluang Kewirausahaan Sekolah Melalui Kreativitas dan Inovasi. April.

Minniti, M., Bygrave, W. D., \& Autio, E. (2005). Global entrepreneurship monitor 2005 Executive Research. Babson College. http://web.esbri.se/pdf/gemglobalreport_2005.pdf

Murdjianto \& Wahid, A. (2006). Membangun Karakter Dan Kepribadian Kewirausahaan. Yogyakarta: Graha Ilmu.

Oukil, M. S. (2009, April). Enhancing Innovation and Entrepreneurship for Growth and Competitiveness of Arab Business Organizations. In The 3rdScientific Forum in Jordan.

Sektiyaningsih, I. S., \& Aisyah, S. (2020). Analisis Pengaruh Pendidikan Kewirausahaan, Inovasi, dan Motivasi Berwirausaha terhadap Minat Berwirausaha pada Mahasiswa IBM Asmi Jakarta. JMBA Jurnal Manajemen dan Bisnis, 6(2), 67-77.

Shane, S., \& Venkataraman, S. (2000). The Promise of Enterpreneurship as a Field of Research. The Academy of Management Review, 25(1), 217. https://doi.org/10.2307/259271

Suryana. (2014). Kewirausahaan, Edisi IV. Jakarta: Salemba Empat.

Tjandrawinata, R. (2016). Industri 4.0: revolusi industri abad ini dan pengaruhnya pada bidang kesehatan dan bioteknologi. February. https://doi.org/10.5281/zenodo.49404

Wei, X., Liu, X., \& Sha, J. (2019). How Does the Entrepreneurship Education Influence the Students' Innovation. Testing on the Multiple Mediation Model. Front. Psychol, 10, 1557. https://doi.org/10.3389/fpsyg.2019.01557

Wibowo, S., \& Pramudana, K. (2016). Pengaruh Pendidikan Kewirausahaan Terhadap Intensi Berwirausaha Yang Dimediasi Oleh Sikap Berwirausaha. None, 5(12), 254215. 